Ius Matrimoniale

27 (2016) nr 2

ks. Tomasz Jakubiak

Papieski Wydział Teologiczny w Warszawie Sekcja św. Jana Chrzciciela

\title{
Czy diakon może w Polsce zgodnie z przepisami Kościoła łacińskiego asystować jako świadek urzędowy przy zawarciu małżeństwa w zwykłych okolicznościach?
}

Dla wszystkich, którzy znają normę prawa kościelnego zapisaną w kan. 1108 § 1 KPK 1983 i kan. 1110 KPK 1983, odpowiedź na postawione w tytule niniejszego artykułu pytanie wydaje się na pierwszy rzut oka oczywista. Zgodnie z treścią przywołanego jako pierwszy kanonu: „Tylko te małżeństwa są ważne, które zostają zawarte wobec asystującego miejscowego ordynariusza albo proboszcza, albo wobec kapłana lub diakona delegowanego przez jednego z nich; a także wobec dwóch świadków, według zasad wyrażonych w następnych kanonach i z uwzględnieniem wyjątków, o których w kan. 144, $1112 \$ 1$, 1116 i $1127 \$ 2-3 ”$. W przywołanym jako drugi przepisie - kan. $1111 \$ 1$ KPK 1983 - ustawodawca zapisał: „Ordynariusz i proboszcz, dopóki ważnie sprawują swój urząd, mogą delegować kapłanom i diakonom również ogólne upoważnienie do asystowania przy zawieraniu małżeństw w granicach swego terytorium”. Z lektury przywołanych norm nie sposób wysunąć wniosku, że zawierają one warunki, od których ustawodawca uzależniałby prawo diakonów do asystowania przy zawieraniu związków małżeńskich.

$\mathrm{Na}$ terenie Konferencji Episkopatu Polski diakoni sporadycznie asystują przy zawarciu związków małżeńskich. A kiedy już mają stać się świadkami urzędowymi zawarcia małżeństwa, towarzyszy im niepewność - czy faktycznie mogą pełnić tę funkcję?- i zwracają się do Kurii diecezjalnej miejsca ślubu z prośbą do ordynariusza o udzielenie specjalnej zgody. 
W związku z pojawiającymi się coraz to nowymi wątpliwościami, należałoby podjąć refleksję nad obecnie obowiązującym prawem, z jednoczesnym odniesieniem do wcześniejszych ustaw prawa powszechnego i partykularnego. Przed przystąpieniem do próby odpowiedzi na postawione w tytule pytanie trzeba odnotować, że autor, zawężając w tytule artykułu okoliczności, w których diakon może być świadkiem urzędowym zawarcia małżeństwa do zwykłych przypadków, pomija okoliczności, o których jest mowa w kan. 144 oraz 1116 KPK $1983^{1}$.

\section{Kolizja praw - zasady ogólne}

Od Soboru Watykańskiego II do dnia obecnego w Kościele wydano wiele przepisów regulujących możliwość zawarcia małżeństwa wobec świadka urzędowego, którym jest diakon. Przepisy te były promulgowane za obowiązywania norm zapisanych w Kodeksie Pio-Benedyktyńskim oraz Kodeksie Jana Pawła II. W związku z tym konieczna wydaje się odpowiedź na pytanie: jaką normy te mają obecnie rangę?

1 Kan. $144 \$ 1$ KPK 1983: „W przypadku błędu powszechnego, faktycznego czy prawnego, a także w przypadku wątpliwości pozytywnej i prawdopodobnej, prawnej lub faktycznej, Kościół uzupełnia wykonawczą władzę rządzenia, zarówno w zakresie zewnętrznym, jak i wewnętrznym. $\$ 2$. Ten sam przepis ma zastosowanie do uprawnień, o których mowa w kan. 882, 883, 966 oraz 1111, §1”. Kan. $1116 \$ 1$ KPK 1983: „Jeśli osoba, zgodnie z przepisem prawa, kompetentna do asystowania jest nieosiągalna lub nie można do niej się udać bez poważnej niedogodności, kto chce zawrzeć prawdziwe małżeństwo, może je ważnie i godziwie zawrzeć wobec samych świadków: $1^{\circ} \mathrm{W}$ niebezpieczeństwie śmierci; $2^{\circ}$ poza niebezpieczeństwem śmierci jedynie wtedy, jeśli roztropnie się przewiduje, że te okoliczności będą trwały przez miesiąc czasu. $\$ 2$. W obydwu wypadkach, gdyby był osiągalny inny kapłan lub diakon, który mógłby być obecny, powinien być poproszony i razem ze świadkami był przy zawieraniu małżeństwa, z zachowaniem zasady ważności małżeństwa wobec samych świadków".

${ }^{2}$ W niniejszym podrozdziale wykorzystano fragmenty: T. JAKUвIAK, Osoba szafarza i przyjmującego sakrament Eucharystii w uchwałach Synodów Archidiecezji 
Część norm dotyczących omawianej materii zamieszczona została w rytuałach, jak chociażby święceń czy małżeństwa. Dzieje się tak dlatego, że Kodeks nie zawiera całego obowiązującego prawa. Nie obejmuje między innymi prawa liturgicznego. Na prawo to składają się normy regulujące przebieg czynności liturgicznych (również tzw. rubryki, które w obrzędach zapisane są kolorem czerwonym ${ }^{3}$ ) oraz normy dyscyplinarne (np. pastoralne zawarte w przedmowach lub instrukcjach). Prawo liturgiczne w swoim charakterze jest częścią systemu prawnego Kościoła katolickiego i podlega pod te same ogólne zasady prawa powszechnego określające sposób: promulgowania, interpretacji, odwołania oraz dyspensowania, jak to ma miejsce w przypadku pozostałych ustaw prawa kościelnego ${ }^{4}$. Kodeksowe przepisy liturgiczne mają charakter nadrzędny w stosunku do pozakodeksowych przepisów liturgicznych ogłoszonych przed promulgacją Kodeksu Jana Pawła II. Te ostatnie, jeśli są sprzeczne z przepisami Kodeksu, utraciły swoją moc (por. kan. 2 KPK 1917; kan. 2, $6 \$ 1$, n. 1-4 KPK 1983) 5 .

Kodeks z 1917 roku podobnie do obecnie obwiązującego Kodeksu dla Kościoła łacińskiego zawierał przepis, w którym najwyższy ustawodawca precyzował, jak należy postępować w przypadku kolizji ustaw (por. kan. 22 KPK 1917, kan. 20 KPK 1983). Według normy wyrażonej w tym kanonie, późniejsza ustawa uchyla wcześniejszą lub ją zmienia, jeśli wyraźnie to postanawia albo jest jej wprost przeciwna, albo porządkuje w całości przedmiot danej ustawy. Przepis ten zawiera zastrzeżenie, z którego wynika, że ustawa powszechna nie zmienia prawa partykularnego lub specjalnego, chyba że co innego jest w prawie wyraźnie zastrzeżone. W tym miejscu należy przypomnieć,

Warszawskiej. Rozprawa doktorska napisana pod kierunkiem ks. prof. dr. hab. Zbigniewa Janczewskiego, Warszawa 2010, s. 70-76.

3 Por. J. M. Huels, Introductory Canons, w: New Commentary on the Code of Canon Law, ed. J. P. Beal, J. A. Coriden, T. J. Green, New York 2000, s. 50.

4 Por. R. Sobański, Kanony wstępne, w: J. Krukowski, R. Sobański, Komentarz do Kodeksu Prawa Kanonicznego, t.1, Poznań 2003, s. 47-48.

5 Por. T. Pawluk, Prawo kanoniczne według kodeksu Jana Pawła II. Tom I, Olsztyn 2002, s. 188. 
że zgodnie z kan. 6 n. 1 KPK 1917 oraz kan. $6 \$ 1$ n. 2 KPK 1983 od dnia obowiązywania kodeksów z 1917 i 1983 roku - przestały obowiązywać ustawy partykularne, przeciwne przepisom kodeksowym, chyba że ustawodawca w kodeksie wyraźnie zastrzegł inaczej.

Jak zauważa Sobański, odpowiedź na pytanie, kiedy jakaś materia jest regulowana ex integro, nastręcza wiele trudności. Praktycznie o regulacji ex integro można mówić wtedy, gdy ogłoszony zbiór przepisów dotyczących odnośnej materii stanowi pewną funkcjonalną całość. Materia jakaś nie jest uregulowana w całości (wyczerpująco), jeśli w dotyczących jej przepisach znajdują się odsyłacze do ustaw specjalnych lub szczegółowych ${ }^{6}$.

Według J. Otaduy, w praktyce trudno określić, w jakim zakresie jest dokonana całkowita reintegracja prawa. Problem tkwi w określeniu zakresu integralnej reorganizacji prawa. Co wyznacza całość w jednym względzie, może wyznaczać część w innym. Na przykład małżeńska przeszkoda może być uważana za całościowy przedmiot w odniesieniu do przeszkód małżeńskich, lecz także jako część małżeństwa. Przeto tylko z brzmienia nowego prawa i różnych okoliczności, które towarzyszą promulgowaniu ustaw, powinniśmy wnioskować, czy prawodawca zamierzał uporządkować przedmiot, czy tylko starał się podtrzymać ważność zastrzeżeń dotyczących treści, gdy określał szczegółowo jakiś punkt. Musimy ostrożnie przeanalizować cel nowego prawa i jego metodę działania w przestrzeni treści, aby zyskać pewne wskazówki co do rozciągłości całości. Trzeba pamiętać, że kodyfikacja prawa zawiera zamiar reorganizacji dużej części instytucji; rezultat jest taki, że ich treść, która zasadniczo została włączona do nowego zbioru prawa, jest uznawana jako abrogowana ${ }^{7}$.

Remigiusz Sobański w komentarzu do kan. 6 obecnie obowiązującego Kodeksu Kościoła łacińskiego stwierdza: „ustawy przeciwne są wtedy, gdy jedna nakazuje lub pozwala to, co druga zakazuje; za

\footnotetext{
6 Por. R. Sobański, Kanony wstępne, art. cyt., s. 47-48.

7 Por. J. Otaduy, Ecclesiastical Laws, w: Exegetical Commentary on the Code of Canon Law, ed. Á. Marzoa, J. Miras, R. Rodríguez-Ocaña, English language ed. E. Caparros, P. Lagges, vol. I, Montreal - Chicago 2004, s. 369-370.
} 
przeciwne KPK trzeba uznać też te, których dyspozycje są nie do pogodzenia"s.

Zgodnie z kan. 22 KPK 1917 oraz kan. 20 KPK 1983, ustawy powszechne nie odwołują prawa partykularnego, chyba że wyraźnie to zostało zaznaczone? . W przypadku braku wzmianki o odwołaniu prawa partykularnego przez ustawodawstwo powszechne - to pierwsze nadal pozostaje w mocy dla jego adresatów ${ }^{10}$. Ani wyraziste przeciwieństwo prawa powszechnego, ani całościowe uporządkowanie przez ustawę powszechną przedmiotu ustawy partykularnej nie skutkuje odwołaniem prawa partykularnego. Trudność stanowi zdefiniowanie „wyraźnej formuły” lub innych słów, które można, w myśl kan. 20 KPK z 1983 roku, uznać za wyraźną formułę odwołania prawa partykularnego. Zdaniem Otaduy’a, przez „wyraźną formułę" możemy rozumieć wyraźne oświadczenie derogacji (proste i ogólne) lub postanowienie derogacji poprzez wyraźne zacytowanie, które prawa partykularne są odwołane ${ }^{11}$. Dzięki pomocy doktryny i praktyki kanonistycznej odpowiedź na postawiony problem nie stanowi trudności. Ogólne postanowienie derogacji typu contrariis quibuscumque minime obstantibus, (lub inne podobne) jest wystarczające. Pogląd ten podzielają A. van Hove, L. Rodrigo, G. Michiels, i jest on akceptowany w praktyce przez Stolicę Apostolską. Według wspomnianego autora, w przypadku braku wyraźnej klauzuli derogacyjnej w nowym prawie - prawo partykularne przeciwne nadal obowiązuje. Podobnie w przypadku „uporządkowania w całości” prawo partykularne, które jest komplementarne do prawa uniwersalnego, również jest obowiązujące. Wraz z uchyleniem ustawy wygasają nawiązujące do niej dekrety wykonawcze i instrukcje ${ }^{12}$.

${ }^{8}$ R. Sobański, Kanony wstępne, art. cyt., s. 52.

9 Por. F. Bączkowicz, J. Baron, W. Stawinoga, Prawo kanoniczne. Podręcznik dla duchowieństwa, t. 1, Opole 1957, s. 213; R. SobańsKi, Ustawy kościelne, w: Komentarz do Kodeksu Prawa Kanonicznego, t. 1..., dz. cyt., s. 78.

10 Por. J. M. Huels, Ecclesiastical Laws..., dz. cyt., s. 83.

11 Por. KPK 1983, kan. 6.

12 Por. KPK 1983, kan. $33 \$ 2,34 \S 2$. 
Norma zawarta w kan. 20 Kodeksu Jana Pawła II nie rozwiązuje problemu obowiązywania prawa partykularnego, gdy późniejsze prawo partykularne ma większą rangę lub zasięg, jak np. pomiędzy prawem diecezjalnym i dekretem ogólnym synodu prowincjonalnego bądź konferencji biskupów. Mimo że nie zachodzi ścisłe podobieństwo pomiędzy opisanym przypadkiem i unormowanym w kan. $20 \mathrm{KPK}$ 1983 roku, przyjmuje się, że wyraźna klauzula derogacyjna w opisanej sytuacji jest także konieczna ${ }^{13}$.

Wraz z promulgacją norm zawartych w Kodeksie Jana Pawła II część wcześniej wymienionych dokumentów papieskich przestało obowiązywać. Zgodnie kan. 6 wspomnianego Kodeksu, od pierwszego dnia Adwentu roku 1983 zostały zniesione powszechne ustawy dyscyplinarne dotyczące spraw regulowanych nowym Kodeksem ${ }^{14}$. Zniesione zostały również inne ustawy, powszechne lub partykularne, przeciwne przepisom Kodeksu z 1983 roku, chyba że odnośnie do partykularnych co innego wyraźnie zastrzeżono (por. KPK 1983, kan. 6).

W tej sytuacji pomocny okazuje się także przepis zawarty w kan. 21 Kodeksu Jana Pawła II. Zgodnie z dyspozycją w nim zawartą, w wątpliwości domniemywa się, że ustawa poprzednia nie została odwołana. Zdaniem ustawodawcy w takiej sytuacji należy normy późniejsze odnieść do poprzednich i w miarę możliwości z nimi uzgodnić.

Na zakończenie niniejszych rozważań należy zwrócić uwagę także na fakt, że biskup diecezjalny na synodzie lub poza nim nie może wydawać ustawy przeciwnej wyższemu prawu ${ }^{15}$. Biskup diecezjalny w sprawowaniu władzy rządzenia nie może działać całkowicie arbitralnie $^{16}$. Władza przysługująca biskupowi diecezjalnemu ma być

\footnotetext{
13 Por. J. Оtaduy, dz. cyt., s. 370-371.

14 Por. R. SobAński, Kanony wstępne, art. cyt., s. 53-54.

15 Por. M. Wijlens, Power of Governance, w: New Commentary..., dz. cyt., s. 189.

16 J. Krukowski, Biskupi diecezjalni, w: Komentarz do Kodeksu Prawa Kanonicznego, red. J. Krukowski, t.II.1, Poznań 2006, s. 251; J. A. Renken, Particular churches and their groups, w: New Commentary..., dz. cyt., s. 527.
} 
sprawowana „zgodnie z przepisami prawa" ${ }^{17}$. Ustawa przeciwna ustawie wyższej rangi jest po prostu nieważna ${ }^{18}$.

\section{Kolizja praw - rozważania szczegółowe}

\subsection{Lumen gentium i Sacrum diaconatus ordinem a KPK 1983}

Po tym teoretycznym wstępie, zanim przystąpię do próby odpowiedzi na pytanie, która norma prawa regulującego asystowanie diakonów przy zawarciu małżeństwa obowiązuje, należy odpowiedzieć na pytanie, jak mają się do siebie normy stanowiące fundament prawa regulującego możliwość delegowania diakonów do asystowania przy zawarciu małżeństwa - n. 29 konstytucji Lumen gentium ${ }^{19}$, n. V.22.4 motu proprio Sacrum diaconatus ordinem ${ }^{20}$ oraz zapisane w kan. 1108 $\$ 1$ i $1111 \S 1$ KPK 1983 - czy uzupełniają się, czy są sobie przeciwne?

\footnotetext{
17 Por. KPK 1983, kan. $391 \S 1$.

18 J. Krukowski, Władza rzadzenia, w: Komentarz do Kodeksu Prawa Kanonicznego, t.1..., dz. cyt., s. 221.
}

19 Sacrosanctum Concilium Oecumenicum Vaticanum II, Constitutio dogmatica de Ecclesia Lumen Gentium, n. 29, 21 XI 1964, AAS 57 (1965), s. 36: Diaconi est, prout ei a competenti auctoritate assignatum fuerit, (...) matrimonio Ecclesiae nomine adsistere et benedicere.

${ }^{20}$ PAulus VI, Motu proprio Generales normae de diaconatu permanenti in Ecclesia Latina restituendo feruntur Sacrum diaconatus ordinem, n. V.22.4, 18 VI 1967, AAS 59 (1967), s. 702: Secundum memoratam Concilii Vaticani II Constitutionem, diaconi est, quatenus loci Ordinarius haec ipsa expedienda commiserit: 4) ubi sacerdos deest, Ecclesiae nomine matrimoniis celebrandis assistere et benedicere ex delegatione episcopi vel parochi, ceteris servatis, quae in C. I. C. iubentur atque firmo manente can. 1098, ubi quae de sacerdote dicuntur, ea de diacono etiam sunt intellegenda. [,Zgodnie ze wspomnianą Konstytucją Soboru Watykańskiego II (Lumen Gentium przyp. własny), do diakona należy, o ile zleci mu to ordynariusz miejsca, tam gdzie nie ma kapłana asystowanie i błogosławienie małżeństwa w imieniem Kościoła na podstawie delegacji biskupa lub proboszcza, z zachowaniem innych wymogów nakazanych w KPK (kan. 1095\$2, 1096 KPK 1917) oraz z zachowaniem mocy kan. 1098 KPK 1917, gdzie to, co mówi się o kapłanie, należy rozumieć o diakonie" - cyt. PaWee VI, Motu proprio Sacrum diaconatus ordinem ustalające normy ogólne dla przywróconego w Kościele łacińskim stałego diakonatu, 18 VI 1967, n. V.22.4, 
Podczas gdy ustawodawca w obecnie obowiązującym Kodeksie Kościoła łacińskiego nie przepisuje żadnych warunków - oczywiście poza otrzymaniem delegacji - od których uzależnia możliwość pobłogosławienia związku małżeńskiego przez diakona, w motu proprio Sacrum diaconatus ordinem zostały przepisane dwa dodatkowe warunki: zlecenie ordynariusza miejsca oraz brak kapłana. W konstytucji Lumen gentium n. 29 ojcowie soborowi nie wspominali nic o otrzymaniu delegacji przez diakona, lecz w sposób ogólny stwierdzili, że diakon może asystować i błogosławić związki małżeńskie „stosownie do tego, co mu wyznaczyła kompetentna władza”.

Biorąc pod uwagę normę zapisaną w kan. 1094 KPK 1917, można przypuszczać, że ojcowie soborowi termin prawniczy, jakim jest „delegowanie władzy przez...”, zastąpili zwrotem: „wyznaczenie przez kompetentną władzę”. Zatem, motu proprio Sacrum diaconatus ordinem zawierało obostrzenie prawa regulującego możliwość asystowania diakonów przy zawarciu związków małżeńskich. Dla odmiany - jeśli uznać, że sformułowanie zapisane w n. V.22.4 motu proprio Sacrum diaconatus ordinem: „o ile zleci mu to ordynariusz miejsca”, zawiera wymóg uzyskania osobnego zlecenia odmiennego od delegacji - jak interpretowali to polscy biskupi zgromadzeni na 124 Konferencji Episkopatu Polski - oznaczałoby to, że sama delegacja jest niewystarczająca i później promulgowane przepisy w 1983 roku były sprzeczne z n. V.22.4 motu proprio Sacrum diaconatus ordinem.

Bardziej uzasadnione wydaje się jednak przypuszczenie, że owo „zlecenie przez ordynariusza miejsca” jest niczym innym, jak uznaniem roli biskupa w moderowaniu, promowaniu i strzeżeniu życia liturgicznego w powierzonym sobie Kościele, co podkreślali ojcowie Soboru Watykańskiego II w konstytucji o liturgii oraz w dekrecie o pasterskich zadaniach biskupów w Kościele (por. kan. $835 \$ 1 \mathrm{KPK}$ $1983)^{21}$. W przeciwnym razie należałoby się spodziewać, że Papieska

w: Posoborowe prawodawstwo kościelne (dokumenty prawno - liturgiczne), zebrał i tł. E. Sztafrowski, tom I, zeszyt 1, Warszawa 1968, n. 492, s. 229.]

21 Sacrosanctum Concilium Oecumenicum Vaticanum II, Constitutio de Sacra Liturgia Sacrosanctum Concilium, n. 26, 04 XII 1963, AAS 56 (1964), s. 107: 
Komisja Interpretacji Dekretów Soboru Watykańskiego II, orzekając o roli nieprzestrzegania klauzuli zawartej w n.V.22.4 motu proprio Sacrum diaconatus ordinem - „tam gdzie nie ma kapłana”, podjęłaby również temat skutku nieprzestrzegania drugiego warunku - mianowicie braku „zlecenia ordynariusza miejsca”22. Mówiąc o orzeczeniu papieskiej komisji z 4 kwietnia 1969 roku, należy podkreślić, że jej członkowie dokonywali autentycznej interpretacji przywołanego motu proprio w duchu konstytucji Lumen gentium n. 29. A skoro n. 29 zawierał warunki, od których uzależniona była ważność błogosławionego małżeństwa, to tym bardziej można przypuszczać, że dla ojców soborowych „wyznaczenie przez kompetentną władzę” jest niczym innym, jak delegowaniem prawa do asystowania przy zawarciu małżeństwa przez kompetentną władzę, i to nie koniecznie ordynariusza miejsca. Jeśli zaś norma V.22.4 motu proprio Sacrum diaconatus ordinem była przeciwna ustawodawstwu promulgowanemu w kodeksie z 1983, to, zgodnie z kan. $6 \$ 1$ n. 2 KPK 1983, przestałaby obowiązywać.

„Actiones liturgicae non sunt actiones privatae, sed celebrationes Ecclesiae, quae est «unitatis sacramentum», scilicet plebs sancta sub Episcopis adunata et ordinata"; Sacrosanctum Concilium Oecumenicum Vaticanum II, Decretum de pastorali episcoporum munere in Ecclesia Christus Dominus, n. 15, 28 X 1965, AAS 58 (1966), s. 679-680: „(..) ipsi itaque Episcopi praecipui sunt dispensatores mysteriorum Dei, sicut et totius vitae liturgicae in Ecclesia sibi commissa moderatores, promotores atque custodes".

22 "R. Utrum, iuxta Litteras Apostolicas Sacrum Diaconatus ordinem, diei 18 iunii 1967, n. 22, 4, collatas cum Constitutione dogmatica de Ecclesia Lumen Gentium, diei 21 novembris 1964, n. 29, clausula ubi deest sacerdos requiratur ad validitatem delegationis quae fit Diacono pro assistendo matrimonio. R. - NEGATIVE, seu clausulam supradictam non esse ad validitatem requisitam". - Pontificia CoMmissio Decretis Concilii Vaticani II Interpretandis, Responsa ad proposita dubia, 04 IV1969, AAS 61 (1969), s. 348; (tłum.: Papieska Komisja Interpretacji Dekretów Soboru Watykańskiego II, Władza dyspensowania przysługująca diakonowi asystującemu przy zawieraniu małżéstwa, w: Posoborowe prawodawstwo kościelne (dokumenty prawno-liturgiczne), zebrał i tł. E. SzTAFrowski, tom III, zeszyt 1, Warszawa 1971, n. 4616-4617, s. 59-60. 


\section{Decyzje KEP a KPK 1983}

Dnia 1 kwietnia 1971 roku biskupi należący do Konferencji Episkopatu Polski przyjęli „Wskazania Episkopatu Polski w sprawie realizacji M.P. Pawła VI Matrimonia mixta”. Zgodnie z treścią dokumentu, postanowiono nie udzielać diakonom zezwolenia na urzędowe asystowanie przy zawieraniu jakichkolwiek małżeństw ${ }^{23}$. Decyzja miała za podstawę prawną klauzulę zamieszczoną w motu proprio Sacrum diaconatus ordinem - „quatenus loci Ordinarius haec ipsa expedienda commiserit" (o ile zleci mu to ordynariusz miejsca) oraz Konstytucji Dogmatycznej o Kościele Lumen gentium - „prout ei a competenti auetoritate assignatum fuerit" (stosownie do tego, co mu wyznaczy kompetentna władza $)^{24}$.Trzy lata później n. 59 Obrzędów sakramentu małżeństwa dostosowanych do zwyczajów diecezji polskich został zaopatrzony przypisem odsyłającym do tejże decyzji biskupów. Zapisano w nim między innymi: „ze względu na warunki duszpasterstwa w Polsce, postanowiono nie delegować diakonów do asystowania przy zawieraniu małżeństw"25.

Podejmując próbę odpowiedzi na pytanie postawione w tytule artykułu - „Czy diakon może zgodnie z przepisami Kościoła łacińskiego asystować jako świadek urzędowy przy zawarciu małżeństwa w zwykłych okolicznościach?” - trzeba ustalić, jaki charakter po promulgacji Kodeksu z 1983 roku posiadają przywołane normy? Czy posiadają nadal charakter wiążący?

Jeśli wskazania Episkopatu traktować jako ustawę, to zastosowanie miałaby w tym przypadku norma zapisana w kan. $6 \$ 1 \mathrm{n} .2 \mathrm{KPK}$

\footnotetext{
23 Por. Konferencja Episkopatu Polski, Wskazania Episkopatu Polski w sprawie realizacji M.P. Pawła VI „Matrimonia mixta”, n. III, 01 IV 1971, Wiadomości Archidiecezjalne Warszawskie 6-7/1971, s. 148.

24 Por. Stefan Cardinalis Wyszyński, Declaratio. Wyjaśnienie w sprawie nie udzielania $w$ Polsce prawa asystowania diakonom przy zawieraniu małżeństw, 11 III 1972, N. 792/72/P, Wiadomości Archidiecezjalne Warszawskie 6/1972, s. 146.

25 Congregatio de Cultu Divino et Disciplina Sacramentorum, Poloniae, 17 XI 1972, Prot. n. 1535/72, w: Obrzędy sakramentu małżéstwa dostosowane do zwyczajów diecezji polskich, Katowice 1974, s. 6 (dalej jako: Obrzędy 1974).
} 
1983. Według niej - od wejścia w życie przepisów KPK 1983 przestały obowiązywać przeciwne ustawy partykularne. Zatem, ten los podzieliłyby również przywołane normy KEP z dn. 1 kwietnia 1971 roku.

Jednakże w tym przypadku kwestia ta wygląda - jak się wydaje nieco inaczej. Nie zagłębiając się w uprawnienia Konferencji Biskupów do podejmowania wspomnianej decyzji, uchwała biskupów podjęta na $124 \mathrm{KEP}$ wydaje się być ogólnym dekretem wykonawczym, mającym za podstawę prawną klauzulę zamieszczoną $\mathrm{w}$ motu proprio Sacrum diaconatus ordinem (o ile zleci mu to ordynariusz miejsca) oraz Konstytucji dogmatycznej o Kościele Lumen gentium (stosownie do tego, co mu wyznaczy kompetentna władza) ${ }^{26}$.

W tym miejscu trzeba stwierdzić, że „Konstytucja dogmatyczna o Kościele” nie może stanowić takiej podstawy prawnej, bowiem ustawodawca nie wspomina w niej nic o potrzebie uzyskania zgody przez diakona od ordynariusza miejsca na bycie delegowanym do asystowania przy zawarciu małżeństwa. Ponieważ z chwilą promulgacji KPK 1983 przestała obowiązywać norma zapisana w V.22.4 motu proprio Sacrum diaconatus ordinem, zatem i decyzja podjęta przez biskupów utraciła swoją moc wiążącą (por. kan. 32, 33 KPK 1983).

Za potwierdzeniem utraty charakteru wiążącego wspomnianej decyzji przemawiają normy zapisane we wszystkich dokumentach biskupów polskich oraz tłumaczeniach rytuałów, wydanych po 1983 roku, w których nie ma już odwołania do decyzji z 124 Konferencji Episkopatu Polski o nieudzielaniu diakonom zezwolenia na urzędowe asystowanie przy zawieraniu jakichkolwiek małżeństw ${ }^{27}$. Wręcz odwrotnie - w większości dokumentów wspomina się, że diakon może przewodniczyć liturgii małżeństwa, jednakże nie podczas Mszy świętej ${ }^{28}$.

\footnotetext{
26 Por. Stefan Cardinalis Wyszyński, dz. cyt., s. 146.

27 Por. Konferencja Episkopatu Polski, Instrukcja Episkopatu Polski w sprawie duszpasterstwa małżeństw o różnej przynależności kościelnej, 14 III 1987 r., w: Dokumenty duszpastersko-liturgiczne Episkopatu Polski 1966-1998, opr. Cz. Krakowiak, L. Adamowicz, Lublin 1999, s. 170-182.

28 Por. Obrzędy sakramentu małżeństwa dostosowane do zwyczajów diecezji polskich, Katowice 1996 (dalej jako: Obrzędy 1996); Konferencja Episkopatu Polski,
} 


\section{Obrzędy święceń diakona, prezbitera i biskupa a KPK 1983}

Z chwilą ogłoszenia drugiego wydania Obrzędów święceń diakona, prezbitera i biskupa - zatwierdzonego przez papieża Jana Pawła II i ogłoszonego przez Kongregację Kultu Bożego i Dyscypliny Sakramentów dnia 29 czerwca 1989 roku - możliwość asystowania diakona przy zawarciu małżeństwa wydaje się na nowo skomplikowana ${ }^{29}$. We Wprowadzeniu teologicznym i pastoralnym do obrzędów wiernie został zacytowany fragment konstytucji Lumen gentium n. 29. Oznacza to, że ustawodawca, cytując nieobowiązującą normę, zobowiązał na nowo wiernych do jej przestrzegania. Dzieje się tak dlatego, gdyż wskazania pastoralne, zawarte $\mathrm{w}$ przedmowach lub instrukcjach obrzędów i rytuałów, stanowią część prawa liturgicznego Kościoła.

Trudno powiedzieć, czy działanie Kongregacji Kultu Bożego i Dyscypliny Sakramentów było celowe, czy też polegało ono na wiernym, ale i mechanicznym zacytowaniu normy z pierwszego wydania Rituale Romanum De Ordinatione Diaconi, Presbyteri et Episcopi z 1968 roku. A może przyświecał jej inny powód?

Za mechanicznym włączeniem starego prawa do obrzędów przemawia fakt, że przygotowaniu drugiego wydania wzorcowego obrzędów przyświecało dokonanie odnowy liturgii. Trudno zatem domniemywać, że ustawodawca przez odwołanie się do starego prawa faktycznie zamierzał zmienić prawo promulgowane w KPK 1983, skoro to drugie wydanie obrzędów, zgodnie z zamysłem ustawodawcy, miało zostać uaktualnione. Tłumaczenie polskie obrzędu

\footnotetext{
Instrukcja dla księży dotycząca matżeństw konkordatowych, 22 X 1998, w: Dokumenty duszpastersko-liturgiczne..., dz. cyt., s. 170-182; Konferencja EpisKopatu Polski, Instrukcja Episkopatu Polski o przygotowaniu do zawarcia małżeństwa w Kościele katolickim, 13 XII 1989 r., w: Dokumenty duszpastersko-liturgiczne..., dz. cyt., s. 123-169.

29 Por. Kongregacja Kultu Bożego i Dyscypliny Sakramentów, Dekret, 29 VI 1989, Prot. CD 145/89, w: Pontyfikał Rzymski odnowiony zgodnie z postanowieniem Świętego Soboru Powszechnego Watykańskiego II wydany z upoważnienia papieża Pawła VI poprawiony staraniem papieża Jana Pawła II. Obrzędy święceń biskupa, prezbiterów i diakonów, drugie wydanie wzorcowe, Katowice 1999, s. 5-6.
} 
zostało zatwierdzone przez Stolicę Apostolską 12 stycznia 1998 roku dekretem, który nie zawierał wzmianki: Contrariis quibuslibet minime obstantibus ${ }^{30}$.

Za tym, że ustawodawca nie miał zamiaru zmieniać ogłoszonego prawa w kan. $1108 \$ 1$ i $1111 \$ 1$ KPK 1983, przemawia fakt, iż w drugim wzorcowym wydaniu Ordo Celebrandi Matrimonium ogłoszonym dnia 19 marca 1990 roku przez Kongregację Kultu Bożego i Dyscypliny Sakramentów, działającą na podstawie specjalnego upoważnienia Jana Pawła II (de speciali mandato Summi Pontificis Ioannis Pauli $I I$ ), pisząc o roli diakona, odwołuje się do Kodeksu Jana Pawła II, a nie do dokumentów Soboru Watykańskiego $\mathrm{II}^{31}$. Jedynym ograniczeniem, jakie przewidywał rytuał, jest to, że ceremonii błogosławienia małżeństw w czasie Mszy św. przewodniczy kapłan.

Dla odmiany za celowym odwołaniem się prawodawcy w odnowionym wydaniu obrzędów święceń do n. 29 konstytucji Lumen gentium, mógłby przemawiać fakt - o czym była mowa wcześniej - że ojcowie soborowi przez wyrażenie: „wyznaczenie przez kompetentną władzę” rozumieli: „delegowanie władzy”. Za tą tezą przemawia również fakt, że Kongregacja ds. Duchowieństwa w art. 33 Directorium pro ministerio et vita diaconorum permanentium - którego część określającą wykonanie powszechnych norm Kościoła należy traktować jako ogólny dekret wykonawczy - opisując uprawnienie diakona stałego do błogosławienia związków małżeńskich, przywołuje prawo promulgowane

\footnotetext{
30 Por. Congregatio de Cultu Divino et Disciplina Sacramentorum, Poloniae, 12 I 1998, Prot. 238/96/L, w: Pontyfikał Rzymski odnowiony zgodnie z postanowieniem Świętego Soboru Powszechnego Watykańskiego II wydany z upoważnienia papieża Pawła VI, poprawiony staraniem papieża Jana Pawła II. Obrzędy święceń biskupa, prezbiterów i diakonów, drugie wydanie wzorcowe, Katowice 1999, s. 4 (dalej jako: Obrzędy święceń biskupa, prezbiterów i diakonów).

31 Por. Congregatio de Cultu Divino et Disciplina Sacramentorum, Decretum, 19 III 1990, Prot. N. CD 1068/89, w: Rituale Romanum ex decreto Sacrosancti Oecumenici Concilii Vaticani II Renovatum Auctoritate Pauli PP. VI Editum Ioannis Pauli PP. II Cura Recognitum. Ordo Celebrandi Matrimonium, Editio typica altera, Typis Vaticanis 1991, Libreria Editrice Vaticana 2008. [dalej jako: Ordo Celebrandi Matrimonium 1991 (2008)].
} 
przez papieża Jana Pawła II w kodeksie z 1983 roku². Jedyna różnica polega na tym, że podczas gdy w Kodeksie nie ma wzmianki, iż diakon sprawuje sakrament małżeństwa poza Mszą św., Directorium art. 33 ją zawierało. Nie bez znaczenia jest - jak wynika z przypisu 99 do normy zawartej art. 33 Directorium - że dykasteria nie dopatruje się sprzeczności pomiędzy n. 29 Lumen gentium, a kan. 1108 KPK 1983 oraz Ordo celebrandi Matrimonium, Ed. typica altera 1991, n. 24, s. $6^{33}$. Gdyby n. 29 Konstytucji dogmatycznej o Kościele jakkolwiek wpływał na zmianę prawa ogłoszonego w kodeksie z 1983 roku oraz Ordo Celebrandi Matrimonium z 1991 roku, to art. 33 Directorium, jako ogólny dekret wykonawczy wyglądałby inaczej. Powodem tego byłby fakt, że jego dekrety, określając sposoby wykonania ustawy lub przynaglając do ich wykonania, musiałyby być oparte na zmienionym prawie, a nie KPK 1983 (por. kan. 32 KPK 1983). Artykuł 33 zawierałby dodatkowo warunek, że diakon oprócz delegacji facultas - powinien uzyskać zgodę kompetentnej władzy.

Pomocne w zrozumieniu zwrotu prout ei a competenti auctoritate assignatum fuerit, z n. 29 Konstytucji dogmatycznej o Kościele, okazują się obrzędy chrztu dzieci ${ }^{34}$. W punkcie 14 Wprowadzenia ogólnego do obrzędów został zamieszczony następujący przepis: „Inni kapłani, a także diakoni, jako pomocnicy biskupa i proboszczów w ich urzędzie przygotowują do chrztu oraz udzielają go, o ile wezwie ich do tego lub wyrazi zgodę biskup albo proboszcz". Można przyjąć, że

\footnotetext{
32 Por. Congregatio Pro Cleris, Directorium pro ministerio et vita diaconorum permanentium, art. 33, 22 II 1998, AAS 91 (1998), s. 896-897 (dalej, jako: Directorium); Congregatio de Institutione Catholica, Congregatio pro Cleris, De diaconatu permanenti. Declaratio Coniuncta, 22 II 1998, AAS 91 (1998), s. 837.

33 Ordo Celebrandi Matrimonium 1991 (2008), n. 24 [tł. polskie: Obrzędy 1996, n. 24, s. 17: Także diakon, który otrzymał upoważnienie od proboszcza lub od miejscowego ordynariusza, może przewodniczyć sprawowaniu sakramentu małżeństwa (por. kan. 1111, KPK 1983), nie wykluczając błogosławieństwa małżonków].

34 Por. Rituale Romanum ex decreto Sacrosancti Oecumenici Concilii Vaticani II Instauratum Auctoritate Pauli PP. VI Promulgatum Ordo Baptismi Parvulorum, Editio typica altera, Typis Polyglottis Vaticanis 1986, (tł. polskie: Obrzędy chrztu dzieci dostosowane do zwyczajów diecezji polskich, Katowice 1994).
} 
interpretacja owego przepisu może stanowić pomoc w wyjaśnieniu n. 29 Lumen gentium, w którym była zawarta analogiczna norma "Zadaniem diakona, stosownie do tego, co mu wyznaczy kompetentna władza, jest uroczyste udzielanie chrztu”. Ponieważ obecnie obwiązujące prawo w Kościele łacińskim nie zna czegoś takiego jak facultas bądź jurysdykcja do udzielania chrztu, tak jak to się dzieje w przypadku małżeństwa - gdzie jest facultas do asystowania przy zawieraniu małżeństw - ustawodawca uznał, że w przypadku chrztu owo „wyznaczenie” to „zgoda lub wezwanie” przez kompetentną władzę, czyli „biskupa” (a dokładnie biskupa diecezjalnego) lub „proboszcza”. Zgodnie z wprowadzeniem do rytuału, diakon do udzielenia chrztu zostaje wyznaczony lub wezwany na takich samych zasadach jak każdy inny kapłan. Biorąc pod uwagę normę zapisaną w kan. 17 KPK 1983, można uznać, że owo wyznaczenie diakona przez kompetentną władzę do asystowania i błogosławienia w imieniu Kościoła związków małżeńskich dokonuje się na takich samych zasadach jak wyznaczenie kapłana do asystowania przy zawarciu małżeństwa ${ }^{35}$. $\mathrm{Z}$ tym jednak zastrzeżeniem, że nie powinien on asystować przy zawarciu małżeństw w czasie Mszy świętej.

Do możliwości zastosowania analogii prawnej w rozwiązaniu postawionego problemu upoważnia również zdanie zamieszczone w pouczeniu, które szafarz święceń diakonatu może odczytać z obrzędu święceń: „Na polecenie biskupa będą mogli głosić kazania i przekazywać Bożą naukę wierzącym i niewierzącym, przewodniczyć modlitwom, udzielać chrztu, asystować przy zawarciu związków małżeńskich oraz je błogosławić, nosić Wiatyk do ciężko chorych i przewodniczyć obrzędom pogrzebu” ${ }^{36}$. Owo „polecenie” jest zatem takie samo - nosi takie same cechy - dla wszystkich wymienionych

\footnotetext{
35 Kan. 17 KPK 1983: „Ustawy kościelne należy rozumieć według własnego znaczenia słów, rozważanego w tekście i kontekście. Jeśli pozostaje ono wątpliwe i niejasne, należy uwzględnić miejsca paralelne, gdy takie są, cel i okoliczności ustawy oraz myśl prawodawcy".

36 Obrzędy święceń biskupa, prezbiterów i diakonów, n. 199, s. 123 (Por. Pontificale Romanum ex decreto Sacrosancti Oecumenici Concilii Vaticani II renovatum auctoritate Pauli PP. VI Editum Ioannis Pauli PP. II cura Recognitum De ordinatione
} 
aspektów posługi diakona, chyba że zostanie to w sposób wyraźny zaznaczone przez kompetentną władzę, w oparciu o przyznane przez najwyższego ustawodawcę uprawnienia, jak ma to miejsce na przykład w kan. 764 KPK $1983^{37}$.

Na marginesie należy zauważyć, że obecnie ograniczenie prawem partykularnym możliwości delegowania diakonom facultas do asystowania przy zawarciu małżeństwa nie jest możliwe, chyba że dotyczyłoby ono pojedynczego duchownego i byłoby ono następstwem aplikacji norm kanonicznego prawa karnego.

Biorąc pod uwagę powyższe argumenty, należy stwierdzić, że przyjmując pogląd (choć nie wydaje się to uzasadnione), że ustawodawca, odwołując się w ogłoszonym po KPK 1983 prawie do normy zawartej w n. 29 Lumen gentium, nałożył na diakonów- mających asystować przy zawarciu małżeństwa - obowiązek uzyskania oprócz delegacji osobnego „wyznaczenia przez kompetentną władzę”; mielibyśmy wtedy do czynienia z wątpliwością prawną. Wówczas, zgodnie z kan. 14 KPK 1983, ustawa zapisana w n. 29 konstytucji dogmatycznej nie obowiązywałaby.

W tym miejscu należy podkreślić, że niezależnie od przywołanych opinii aktualna pozostaje preferencja wyrażona przez prawodawcę w punkcie 29 Wprowadzenia teologicznego i pastoralnego do obrzędów małżeństwa, zgodnie z którą: małżeństwo zasadniczo powinno się zawierać w czasie Mszy. Za zawarciem małżeństwa poza Mszą przemawiają między innymi: potrzeby duszpasterskie, stopień udziału w życiu Kościoła narzeczonych i uczestników uroczystości ${ }^{38}$.

episcopi, presbyterorum et diaconorum, editio typica altera, Typis polyglottis Vaticanis 1990, n. 199, s. 106).

37 KPK 1983, kan. 764: „Z zachowaniem przepisu kan. 765, prezbiterzy i diakoni posiadają wszędzie władzę przepowiadania, za domyślną przynajmniej zgodą rektora kościoła, chyba że ta władza została ograniczona lub odwołana przez kompetentnego ordynariusza, albo na podstawie prawa partykularnego jest wymagane wyraźne zezwolenie".

38 Por. Obrzędy 1996, n. 29, s. 18; Ordo Celebrandi Matrimonium 1991 (2008), n. 29, s. 6-7. 


\section{Opinie kanonistów}

Wśród kanonistów przeważa pogląd, że diakoni mogą być świadkami urzędowymi zawarcia małżeństwa.

Serrano i Góralski w komentarzu do kan. 1108 KPK 1983, pisząc o duchownych mogących otrzymać delegację facultas potrzebnego do asystowania przy zawarciu małżeństwa, wymieniają diakonów przy jednoczesnym zestawieniu ich z biskupami niebędącymi ordynariuszami. Według wspomnianych autorów, diakoni są delegowani na takich samych warunkach jak inni kapłani ${ }^{39}$. Podobne zdanie reprezentuje Dyduch. W opracowaniu poświęconym między innymi uprawnieniom diakonów stałych wyraża pogląd, że mogą oni, jeśli otrzymają delegację lub subdelegację, asystować przy zawieraniu związków małżeńskich i udzielać nowożeńcom błogosławieństwa ślubnego w imieniu Kościoła. Kanonista dodaje jednak jeden warunek, od którego uzależnia sprawowanie przez diakonów funkcji świadka urzędowego. Twierdzi, że powinni być oni świadkami urzędowymi małżeństw zawieranych poza Mszą świętą ${ }^{40}$.

Podobną opinię co Dyduch reprezentuje Huels. Powołując się na normy zapisane „Obrzędach błogosławieństw”, zauważa, że diakon może udzielać błogosławieństw w czasie obrzędu małżeństwa, któremu przewodniczy ${ }^{41}$. Jednak gdy jest obecny kapłan, stosowniej jest, aby on przejął obowiązek przewodniczenia, a diakon, aby mu usługiwał w czynności liturgicznej, wykonując to, co do niego należy ${ }^{42}$.

\footnotetext{
39 Por. J. M. Serrano Ruiz, De forma celebrationis matrimonii, w: Studium Romanae Rotae. Corpus Iuris Canonici. I. Commento al Codice di Diritto Canonico, red. P. V. Pinto, Libreria Editrice Vaticana 2001, s. 660; W. Góralski, Małżeństwo, w: Komentarz do Kodeksu Prawa Kanonicznego, t. III.2, red. J. Krukowski, Poznań 2011, s. 314.

40 Por. J. Dyduch, Diakonat stały w świetle dokumentów Stolicy Apostolskiej, Prawo Kanoniczne 42 (1999), nr 1-2, s. 70.

41 Por. J. M. Huels, Other Acts of Divine Worship, w: New Commentary..., dz. cyt., s. 1403.

42 Cyt. Obrzędy błogosławieństw dostosowane do zwyczajów diecezji polskich, t. 1, Katowice 1994, n. 18, s. 16. (Por. Rituale Romanum ex decreto Sacrosancti
} 
Zdaniem Huelsa, zasada ta nie ma zastosowania, kiedy kapłan jest przeszkodzony moralnie, np. kiedy jego obecność jest anonimowa albo nieprzewidywalna ${ }^{43}$.

Obecnie do przyjęcia delegacji diakoni nie potrzebują wyraźnego zlecenia ze strony ordynariusza miejsca, jak to przewidywał ustawodawca w Sacrum diaconatus ordinem n. V.22.4. Wniosek taki poprzez analogię można wysnuć $\mathrm{z}$ analizy wypowiedzi Blanco na temat zwyczajnego szafarza chrztu ${ }^{44}$.

Na marginesie należy zauważyć, że posiadanie przez diakona ogólnej delegacji od ordynariusza nie jest wcale tożsame - zdaniem Woodall'a - z tym, że ma on prawo do asystowania przy zawarciu wszystkich bez wyjątku małżeństw w granicach parafii, na terenie której posiada facultas. Mimo że potencjalnie mógłby być świadkiem urzędowym, przy każdym małżeństwie zawieranym na terenie parafii (oczywiście przy zachowaniu pozostałych przepisów prawa kanonicznego, jak np. dotyczących przynależności obrządkowej przyszłych małżonków), to jednak przede wszystkim do proboszcza należy prawo błogosławienia związków zawieranych na terenie powierzonej jego pieczy parafii. Wspomina o tym ustawodawca w normie zapisanej w kan. 530 n. 4 KPK 1983. Zgodnie z jego dyspozycją, do funkcji specjalnie powierzonych proboszczowi należy asystowanie przy zawieraniu małżeństw i błogosławieniu małżeństw ${ }^{45}$. W tym miejscu trzeba również nadmienić, że użyte w kanonie sformułowanie: „do funkcji specjalnie powierzonych proboszczowi należą...” - nie oznacza, że funkcje te zostały wyłącznie powierzone do wykonywania

Oecumenici Concilii Vaticani II Instauratum Auctoritate Ioannis Pauli II Promulgatum De Benedictionibus, Editio iuxta typica, Liberia Editrice Vaticana 1984, n. 18, s. 14.)

43 Por. J. M. Huels, Other Acts..., dz. cyt., s. 1403.

44 Por. M. Blanco, Baptism, w: Exegetical Commentary on the Code of Canon Law, ed. Á. Marzoa, J. Miras, R. Rodríguez-Ocaña, English language ed. E. CAPARRos, P. Lagges, vol. III/1, Montreal - Chicago 2004, s. 453.

${ }^{45}$ Por. G. J. Woodall, A Passion for Justice. An Introductory Guide to the Code of Canon Law, Gloucester 2011 s. 410. 
proboszczowi $^{46}$. Zakaz błogosławienia związku małżeńskiego na terenie parafii wyrażony przez proboszcza względem diakona - mającego delegację od ordynariusza miejsca - nie będzie miał wpływu na ważność pobłogosławionego związku, a jedynie na niegodziwość. Sytuacja mogłaby inaczej wyglądać, gdyby facultas subdelegował duchowny mający delegację ogólną od proboszcza zakazującego diakonowi pobłogosławienie związku.

Zdarzają się jednak autorzy - jak chociażby Counce - którzy odwołując się do ograniczenia zawartego w motu proprio Sacrum diaconatus ordinem (n.V.22.4) - „tam gdzie nie ma kapłana” - oraz preferencji liturgicznej, zgodnie z którą posługa kapłana ma pierwszeństwo przed posługą diakona, stwierdzają, że współcześnie diakon nie powinien asystować przy zawarciu małżeństwa, jeśli obecny jest nieprzeszkodzony kapłan. Przeszkody mogą być różnego rodzaju i fizyczne i legalne. Do pierwszej grupy autor zalicza między innymi: chorobę lub podeszły wiek kapłana, posiadanie przez diakona delegacji do asystowania małżeństwa - przy jednoczesnej niemożliwości uzyskania takowego uprawnienia dla obecnego kapłana. Do drugiej grupy - przeszkód legalnych - Cuence zalicza nieznajomość przez kapłana języka, którym posługują się nupturienci. Kanonista przewiduje odstępstwa od powyższej zasady. Do okoliczności usprawiedliwiających pobłogosławienie małżeństwa przez diakona, mimo obecności nieprzeszkodzonego kapłana - nawet podczas Mszy - zalicza również czynniki „specjalne” bądź też „personalne”. Mogą nimi być np.: spokrewnienie z którąś ze stron zawierających małżeństwo; prowadzenie przez diakona przygotowania do sakramentu małżeństwa, na skutek czego nupturienci proszą go o posługę podczas ceremonii. Według Clouce, klauzula zapisana w motu proprio Sacrum diaconatus ordinem ma na celu okazanie szacunku hierarchicznej strukturze Kościoła oraz legalnemu rozróżnieniu liturgicznych ról. Autor jest świadomy, że istnieją kanoniści - jak chociażby Ditewing - którzy zawsze zezwalają diakonowi na asystowanie przy zawarciu małżeństwa w czasie

46 Por. J. A. Renken, Parishes, Pastors, and Parochial Vicars, w: New Commentary..., dz. cyt., s. 702. 
Mszy $^{47}$. Cluence wyraża pogląd, że złamanie wskazania motu proprio Sacrum diaconatus ordinem wpływa na godziwość, a nie ważność ${ }^{48}$, co jest zgodne z odpowiedzią Papieskiej Komisji Interpretacji Dekretów Soboru Watykańskiego II z 4 kwietnia 1968 roku $^{49}$.

Podobnie, według Huelsa, rzecz się ma z błogosławieniem małżeństwa przez diakona posiadającego delegację od proboszcza, mimo jednoczesnego zakazu ze strony biskupa miejsca, na terenie diecezji którego jest wykonywana funkcji. W swoim rozważaniu na temat diakonów stałych, które poprzez analogię można odnieść do pozostałych diakonów, autor zauważa, że diakon posiadający delegację od proboszcza miejsca, bez aprobaty ordynariusza tegoż proboszcza, będzie świadkiem urzędowym zawarcia małżeństwa ważnie, choć niegodziwie. Brak zgody ze strony ordynariusza na wypełnianie funkcji diakońskich na terenie podległym wspomnianemu ordynariuszowi wpływa jedynie na niegodziwość wykonywania posługi. W uzasadnieniu reprezentowanego poglądu autor zaznacza, że mimo iż diakon święcony jest dla posługi w Kościele, to jednak Kościoła rozumianego lokalnie - podległego biskupowi miejsca. Choć uprawnienia ministerialne diakonów wynikają z przyjętych święceń, a nie z przypisania do jakiegokolwiek urzędu, to jednak nie można zapominać, że w wykonywaniu uprawnień diakon podlega ordynariuszowi ${ }^{50}$.

Wśród kanonistów znaleźli się również i tacy, którzy rozważali możliwość asystowania diakona przy związku zawieranym przez katolika obrządku wschodniego. Zgodnie z tradycją Kościołów katolickich wschodnich, zapisaną w kan. $828 \mathrm{KKKW}$, diakon nie może

\footnotetext{
47 Por. W. T. Ditewig, 101 Questions and Answers on Deacons, New Jersey 2004, s. 93.

48 Por. P. D. Counce, Canon 1108: Deacon Assisting at a Marriage During Mass, Roman Replies and CLSA Advisory Opinions 2006, ed. F. S. Pedone, P. D. Counce, s. 70-71.

49 Por. Pontificia Commissio Decretis Concilii Vaticani II Inter pretandis, dok. cyt., s. 348.

50 Por. J. M. Huels, Canon 1008: Deacon Seeking to Minister Outside His Diocese of Incardination, Roman Replies and CLSA Advisory Opinions 2002, ed. F. S. PEDonE, J. I. Donlon, Washington 2004, s. 111.
} 
błogosławić takich małżeństw, gdyż w przeciwnym razie byłoby ono nieważne ${ }^{51}$. Gallaro nie do końca zgadza się z tym stwierdzeniem. Autor odwołując się do sytuacji, w której zachodzi kolizja praw a dokładnie normy zapisanej w kan. 828 KKKW i kan. 1108 KPK 1983 - wysunął tezę, że ważne jest małżeństwo pobłogosławione przez diakona łacińskiego delegowanego przez łacińskiego ordynariusza, jeśli katolik obrządku wschodniego podlega pod jurysdykcję łacińskiego ordynariusza ${ }^{52}$.

Interesująca $\mathrm{z}$ punktu widzenia prawa partykularnego obowiązującego na terenie Polski jest opinia Gajdy. Wypowiadając się na temat zdatności diakona do asystowania przy zawarciu małżeństwa, stwierdził, że „konsekwentnie do przepisu zawartego w kan. 1111 \$1 instrukcje Episkopatu Polski z 1986 i 1998 roku nie kwestionują możliwości delegowania diakonowi władzy błogosławienia małżeństw"53.

Analiza obowiązywania dekretów biskupów należących do Konferencji Episkopatu Polski o tyle jest istotna, że wcześniej - przed publikacją Kodeksu z 1983 roku, dnia 1 kwietnia 1971 roku - biskupi obecni na 124 Konferencji Episkopatu Polski - biorąc pod uwagę „warunki pracy Kościoła w Polsce” - podjęli decyzję o nieudzielaniu diakonom zezwolenia na urzędowe asystowanie przy zawieraniu jakichkolwiek małżeństw ${ }^{54}$.

Do dokumentu z dnia 1 kwietnia 1971 roku odniósł się Pawluk, twierdząc, że nie miał on charakteru ustawy. Zdaniem autora,

\footnotetext{
${ }^{51} \mathrm{KKKW}$ kan. $828 \$ 1$ : „Tylko te małżeństwa są ważne, które są zawierane z zachowaniem świętego obrzędu wobec hierarchy miejsca lub proboszcza miejsca lub kapłana, który od jednego z nich otrzymał upoważnienie do błogosławienia małżeństw i wobec przynajmniej dwóch świadków, jednak według kanonów, które następują, z uwzględnieniem wyjątków, o których mowa w kan. 832 i $834 \$ 2$ ".

52 Por. G. D. Gallaro, Canon 1108: Latin Deacon Assisting at Marriage of Two Eastern Catholics, Roman Replies and CLSA Advisory Opinions 1995, ed. K. W. VANn, J. I. Donlon, s. 91-92.

53 Por. M. Gajda, Prawo małżeńskie Kościoła katolickiego, Tarnów 2005, s. 171.

54 Por. Konferencja Episkopatu Polski, Wskazania..., n. III, dz. cyt., s. 148.
} 
należało go rozumieć jako zwykłą dyrektywę, a nie ustawę uniezdalniającą diakona do asystowania przy ślubie ${ }^{55}$.

\section{Podsumowanie}

Zgodnie z aktualnie obowiązującym prawem, diakon może asystować przy zawarciu małżeństwa w zwykłych warunkach na podstawie delegacji od ordynariusza miejsca bądź proboszcza. Winien jednak funkcję tę wypełniać poza Mszą św.; nie wobec małżeństw zawieranych przez wiernego obrządku rzymskokatolickiego $\mathrm{z}$ wiernym kościoła wschodniego (katolikiem i niekatolikiem) ${ }^{56}$.

Jeśli jednak przyjąć za prawdziwy pogląd, według którego diakon oprócz delegacji facultas do asystowania przy zawarcia związku małżeńskiego potrzebuje zgody ordynariusza miejsca - ewentualnie biskupa - wtedy to brak owej zgody, przy jednoczesnym posiadaniu facultas, wpływałby jedynie na niegodziwość posługi, a nie ważność zawartego małżeństwa. Wniosek taki można wysnuć $\mathrm{z}$ analizy normy zapisanej w kan. 10 KPK 1983, zgodnie z którym: „Jedynie te ustawy należy uznać za unieważniające lub uniezdalniające, które wyraźnie postanawiają, że akt jest nieważny albo osoba niezdolna”. W omawianym przypadku z pewnością nie może być mowy o wyraźnym postanowieniu prawa uniezdalniającym diakona - posiadającego facultas do asystowania przy zawarciu małżeństwa - do ważnego dokonania czynności prawnej, jeśli diakon ten nie posiada zgody ordynariusza bądź działa wbrew zakazowi ordynariusza.

W dyskusjach na temat możliwości asystowania diakonów przy zawarciu małżeństwa, czasami pojawiają się opinie „podawane w formie „przekazów” czy „legend”, zgodnie z którymi: „diakoni w danej diecezji nie mogą spełniać owej czynności prawnej, gdyż: „kiedyś”, w „jakichś okolicznościach” biskup diecezjalny „miał powiedzieć”, że

\footnotetext{
55 T. PAwluk, Prawo kanoniczne według kodeksu Jana Pawła II. Tom III. Prawo mał̇̇eńskie, Olsztyn 1996, s. 180.

56 Por. KKKW, kan. 828; U. NowICKA, Stwierdzenie stanu wolnego wiernych prawosławnych na forum Kościoła katolickiego, Warszawa 2012, s. 291-292.
} 
diakon, aby móc asystować przy zawarciu małżeństwa, musi uzyskać zgodę biskupa diecezjalnego". Tak wyrażony pogląd przez biskupa diecezjalnego trudno określić mianem prawa. Nawet, gdyby biskup owo zdanie faktycznie wypowiedział, nie sposób byłoby ów zakaz traktować, jako prawnie wiążący, gdyż: nie spełnia on kryteriów właściwej promulgacji (por. kan. 7 KPK 1983), nie ma podstawy prawnej - jeśli uznać, że miał być odpowiednikiem dekretu wykonawczego (por. kan. 33 KPK 1983), jest sprzeczny z prawem powszechnym (por. kan. 135, 391 KPK 1983). Zakaz taki można uznać jedynie jako wyraz troski biskupa diecezjalnego o sprawowany kult Boży w powierzonej jego pieczy diecezji. Jeśli jednak wbrew przytoczonym argumentom, utrzymywałby ktoś nadal, że zakaz ten nadal obowiązuje, to należy stwierdzić, że mamy w tym przypadku do czynienia $\mathrm{z}$ wątpliwością prawną; wtedy to, zgodnie z wolą najwyższego ustawodawcy wyrażoną w kan. 14 KPK 1983, ustawa taka nie obowiązuje.

\section{Whether the deacon can, according to regulations of the Latin Church, assist as The Official Witness at the solemnization of a marriage in ordinary circumstances?}

\section{Summary}

According to the belief prevailing in Poland that the deacon cannot assist at the marriage, the author enquires whether the practice of blessing marriages only by the priests is consistent with the law of the Roman Catholic Church. In his discussion, the author goes back to the norms written in the Second Vatican Council constitution Lumen Gentium and the Apostolic Letter of Pope Paul VI Sacrum Diaconatus Ordinem - consisting the basis of legislation regulating the considered matter. Subsequently, applying the general norms of the code of Canon Law about the collisions of law, he is answering a question about the value of the documents released by the Apostolic See and Polish Bishop's Conference since 1983. In conclusion, the author notes that if, contrary to the cited arguments, someone would still insist that the deacon, beyond the delegation needs a specific consent of the local ordinary, it should be noted that in this case it is a doubt about the lawand such law do not oblige. 